HISTORIA $68,2019 / 4,413-435$

DOI 10.25162/HISTORIA-2019-0022

JEFFREY ROP

\title{
The Phocian Betrayal at Thermopylae
}

\begin{abstract}
This article makes three arguments regarding the Battle of Thermopylae. First, that the discovery of the Anopaea path was not dependent upon Ephialtes, but that the Persians were aware of it at their arrival and planned their attacks at Thermopylae, Artemisium, and against the Phocians accordingly. Second, that Herodotus' claims that the failure of the Phocians was due to surprise, confusion, and incompetence are not convincing. And third, that the best explanation for the Phocian behavior is that they were from Delphi and betrayed their allies as part of a bid to restore local control over the sanctuary.
\end{abstract}

Keywords: Thermopylae - Artemisium - Delphi - Phocis - Medism - Anopaea

The courageous sacrifice of Leonidas and the Spartans is perhaps the central theme of Herodotus' narrative and of many popular retellings of the Battle of Thermopylae in 480 BCE. Even as modern historians are appropriately more critical of this heroizing impulse, they have tended to focus their attention on issues that might explain why Leonidas and his men fought to the death. These include discussion of the broader strategic and tactical importance of Thermopylae, the inter-relationship and chronology of the Greek defense of the pass and the naval campaign at Artemisium, the actual number of Greeks who served under Leonidas and whether it was sufficient to hold the position, and so on. While this article inevitably touches upon some of these same topics, its main purpose is to reconsider the decisive yet often overlooked moment of the battle: the failure of the 1,000 Phocians on the Anopaea path.

I make three arguments regarding the Phocian defense of the path at Thermopylae, aspects of which have been raised before but have not been widely accepted by scholars. First, that the discovery of the Anopaea was not dependent upon the treachery of Ephialtes, but that the Persians were aware of it from the moment of their arrival and planned their attacks at Thermopylae, Artemisium, and against the Phocians accordingly. Second, that Herodotus' claims that the failure of the Phocians was due to surprise, confusion, and incompetence are not convincing. And third, that the best explanation for the Phocian behavior is that they were from Delphi and betrayed their allies in a bid to restore local control over the oracle of Apollo. One consequence of these arguments is to recast the reasons for the Persian success at Thermopylae. Rather than being a fortunate victory owing to the treachery of a single individual, Xerxes and his generals drove the heavily armed Greeks from a highly defensible position following the disciplined execution of a sensible tactical plan that took advantage of local terrain and exploited vulnerabilities in the nascent anti-Persian alliance. 


\section{Ephialtes and Persian Plan of Attack}

Several scholars have previously doubted Herodotus' claim $\left(7.213^{1}\right)$ that the Persian invasion was saved from the brink of failure by the fortuitous appearance of local traitor and guide Ephialtes after only two days of fighting at Thermopylae. ${ }^{2}$ Even so, many others continue to hold that without him the Persians would have never discovered the Anopaea path and in turn never defeated Leonidas and the Greeks. ${ }^{3}$ Before addressing the Phocian failure on the Anopaea, then, it is worth reviewing the case against Persian dependence upon Ephialtes.

The Persians had long experience waging wars in the mountainous regions of their homeland and throughout the Achaemenid Empire. The idea that a flanking maneuver did not occur to Xerxes and his generals prior to Ephialtes' appearance is implausible. Similarly problematic is the notion that the King would have ordered a night march along the Anopaea immediately after learning of its existence, putting his elite Immortals at risk of an ambush without first scouting the path or its defenders. The Persian army had scouts, as Herodotus himself reports (7.208), and Burn is correct to observe that, "it may be safely assumed that reconnaissance began on the day of the arrival of the first Persian cavalry".

Persian ground forces arrived four days before hostilities commenced and six days before the decisive march on the Anopaea (7.210.1).5 They therefore had nearly a full week to survey the local terrain and to observe the Greek defenders on the path and at the Gates themselves. In addition to his own Persians, Xerxes had allied Greek scouts and informants at his service. Most notable among these were the Thessalians, who had campaigned against the Phocians and even used the path within living memory

1 All citations of ancient sources are to Herodotus unless otherwise noted.

2 Macan (1908), 315-319, and (vol. 2), 233 persuasively argues that Ephialtes was a scapegoat in the later rehabilitation of Delphi against charges of medism; How and Wells (1912), 225; Burn (1962), 407-413; Hignett (1963), 145; Georges (1986), 53; Dandamaev (1989), 200; Szemler, Cherf, and Kraft (1996), 73-74. For the literary and thematic role played by Ephialtes in Herodotus' account, see Immerwahr (1966), 261-263.

3 Grundy (1901), 299-300; Olmstead (1948), 252; Pritchett (1958); Lazenby (1964), 271 and (1993), 140-141; Munro (1964), 293-300; Hammond (1988), 555-556; Balcer (1995), 252; Green (1996), 137-138; Cartledge (2007), 146; Stoneman (2015), 135

4 Burn (1962), 407. Simpson (1972), 4-5 cites Xerxes' experience in mountain warfare as the reason the Persians outmaneuvered the Phocians. See also Dandamaev (1989), 200. Briant (2002), 374-376 surveys the various Gates found in the Achaemenid Empire, and concludes by pointing out that they were hardly invulnerable: "in every case, they could be circumvented via footpaths pointed out by local peasants and herdsmen - exactly the way that Thermopylae fell into the hands of the Persians in 480 ." See also Hignett (1963), 133. Herodotus notes that the Greeks themselves recognized the danger of being turned by the placement of the Phocians on the Anopaea and by their withdrawal from Tempe earlier (7.173.4).

5 Scholars have failed to reach a consensus on the calendar dates for the Persian journey from Therma to Thermopylae and Artemisium, as Herodotus' diary of the Persian invasion is often unclear or inconsistent. Sacks (1976) makes the case for mid-September, and is followed by Hammond (1988), 570, but most appear to favor the month of August, See How and Wells (1912), 372-375; Maurice (1930), 212-213; Burn (1962), 403-405; Dascalakis (1962), 89-110, 185-187; Hignett (1963), 448-453; Hammond (1982), 75-82 and (1988), Table 4; Lazenby (1993), 118-119; Stoneman (2015), 226-228. My argument here is not especially dependent upon either proposed date. 
(7.215). ${ }^{6}$ The Persians could also recruit or compel locals familiar with the terrain from nearby settlements such as Malis, much as Xenophon's Ten Thousand did on their march from Cunaxa eighty years later.7 Herodotus' comment that there was confusion over the identity of the individual who actually led the Immortals on the path may be an indication that multiple Greeks, not only Ephialtes, actually served the Persians as guides $(7.213-214)$.

Another sign that the King was aware of the advantages of flanking the Greek position is that the attempted circumnavigation of Euboea began immediately upon the arrival of the fleet at Aphetae. ${ }^{8}$ Some debate remains over the exact timing of the battles at Thermopylae and nearby off the coast of Artemisium, but there is no denying the tactical codependence of these positions. Once either fell, there was little reason for Greek forces to remain at the other. ${ }^{9}$ Herodotus' comment that fighting on land and sea occurred over the same three days thus makes sense from a tactical perspective (8.15.1), and privileging it over a few other potentially (but not necessarily) contradictory statements results in the following relative chronology of the engagement. ${ }^{10}$

\begin{tabular}{|l|l|l|}
\hline & Events on Land & Events at Sea \\
\hline Day 1 & $\begin{array}{l}\text { Persian army arrives, begins day 1 of } \\
\text { four day wait (7.210). }\end{array}$ & $\begin{array}{l}\text { Persian fleet arrives at Cape Sepias on the } \\
\text { Magnesian coast (7.188.1). }\end{array}$ \\
\hline Day 2 & Waiting, day 2. & $\begin{array}{l}\text { Struck by storm in morning, Persian fleet } \\
\text { remains in place for three days (7.188.2-3). }\end{array}$ \\
\hline
\end{tabular}

6 This earlier war between Thessaly and Phocis probably broke out after 510, according to McInerney (1999), 177. For further discussion of the Thessalian hegemony in central Greece and the date of the Phocian revolt against it, see Larsen (1968), 18-19, 40-48; Lehmann (1983); Beck (1997), 109 n. 13. On the revolt itself, see Macan (1908), 393-397; How and Wells (1912), 242; Hignett (1963), 145; Rahe (2015), 246-248. Westlake (1936) notes that medism in Thessaly among at least the Aleuadae predated the invasion of Xerxes by at least a decade. Against this position, see Brunt (1953), 162-163.

7 For discussion and references, see Waterfield (2006), 132-134; Lee (2007), 33.

8 Beloch (1931), 87-90 and Hignett (1963), 164, 182-183 doubt that the Persians ever attempted a circumnavigation, but see the counter argument by Bowen (1998), 361-362.

9 Bury (1895-1896), 84-86; Munro (1902), 312; How and Wells (1912), 371-372; Evans (1969), 390-391. For recent treatments of the Greek strategy that emphasize the coordination between land and sea forces, see Matthew (2009) and (2013).

10 The controversy is due to several statements that contradict this comment, namely that the army allowed four days to pass before attacking upon its arrival (7.210); that the fleet arrived at Aphetae three days after the army did at Thermopylae (7.196); and that the Persian fleet remained at Cape Sepias for three days because of the storm, which abated on the fourth day (7.192.1). I have chosen to privilege the statement that the fighting took place over the same three days, and reconciled these discrepancies - which may be explained in part simply by the fact that every contingent in the Persian army may not have reached the pass on the same day - by counting the day of the Persian army's arrival as the first day of its wait, but not as one of the three days prior to the fleet's arrival. On this arrangement, see Immerwahr (1966), 257-258 n. 62. Most scholars have adopted a relative timeline close to, if not exactly the same as, the one proposed here. See Bury (1895-1896), 95-97; Grundy (1901), 319-341; Macan (1908 vol. 2), 275-286; Burn (1962), 395-400; Dascalakis (1962), 149-170, 185-187; Hignett (1963), 379-385; Evans (1969), 401 n. 86; Lazenby (1993), 119; Green (1996), 124-144. Stoneman (2015), 227-228 recently posited that the battles on land and sea took place on entirely separate days, but this is in direct contradiction to Herodotus' statement and to the tactical reliance of the defensive positions on one another. 


\begin{tabular}{|l|l|l|}
\hline & Events on Land & Events at Sea \\
\hline Day 3 & Waiting, day 3. & Persian fleet remains in place, day 2. \\
\hline Day 4 & Waiting, day 4. & Persian fleet remains in place, day 3. \\
\hline Day 5 & $\begin{array}{l}\text { Persian army attacks Greek posi- } \\
\text { tion at Thermopylae, is repulsed } \\
\text { 7.210-212). }\end{array}$ & $\begin{array}{l}\text { Persian fleet arrives at Aphetae in early after- } \\
\text { noon (8.6), is attacked by Greek fleet in late } \\
\text { afternoon (8.9-11). } \\
\text { A Persian detachment begins circumnavigation } \\
\text { of Euboea by sailing around Sciathus, but is } \\
\text { destroyed by an overnight storm (8.7, 13). }\end{array}$ \\
\hline Day 6 & $\begin{array}{l}\text { Persian army attacks Greek position } \\
\text { at Thermopylae, is repulsed (7.212). } \\
\text { In the evening, Persian Immortals } \\
\text { set out on Anopaea path (7.215). }\end{array}$ & $\begin{array}{l}\text { 53 ships arrive to reinforce Greek fleet, minor } \\
\text { skirmishing in late afternoon at sea (8.14). }\end{array}$ \\
\hline Day 7 & $\begin{array}{l}\text { Persian army surrounds remaining } \\
\text { Greek forces, destroying or captur- } \\
\text { ing them (7.223-225). }\end{array}$ & $\begin{array}{l}\text { Persian fleet launches attack on Greeks, fights to } \\
\text { a draw (8.15-18). } \\
\text { Greeks retreat in evening after learning of defeat } \\
\text { on land (8.21). }\end{array}$ \\
\hline Day 8 & $\begin{array}{l}\text { Persian army remains at Thermo- } \\
\text { pylae (8.23-24). }\end{array}$ & $\begin{array}{l}\text { Persian fleet seizes Histiaia, Persian sailors visit } \\
\text { Thermopylae (8.23-24). }\end{array}$ \\
\hline
\end{tabular}

The Persian army moved against the Greek defenders on the fifth day after its arrival, the same day that the fleet reached nearby Aphetae. The ground assault coincided with two actions at sea: while one part of the fleet - 200 ships, according to Herodotus - ventured into open waters to attempt the doomed passage around Euboea, the other engaged the Greek fleet off Artemisium. Of these three movements, the circumnavigation of Euboea had the greatest potential. Had it been completed successfully, Persian marines and ships would have surrounded and probably annihilated the Greek defenders on both land and sea.

The circumnavigation began in the afternoon of Day 5. The island of Euboea is roughly 180 kilometers in length, and a trireme at maximum efficiency and under favorable weather conditions could sail about 240 kilometers in a day. ${ }^{11}$ Given the weather conditions, the initial path that took them around Sciathus in order to conceal their movements from the Greeks, and the likelihood that the narrows between Euboea and

11 Figures for the speed of a trireme are from van Wees (2004), 206, but see also Casson (1991), 84-85. Rahe (2015), 230 asserts that the circumnavigation of Euboea would take three days, but does not explain his reasoning. Macan (1908), 367-368 calculates a travel time of 36 hours. Hammond (1988), 553 suggests that it could have been performed in as few as 25 hours. In any case, Xerxes could hardly have counted on the fleet making the best possible time. For the difficulties that might slow a fleet attempting the maneuver, see How and Wells (1912), 210-211. Even conceding that the Persians could have accomplished the feat in 25 hours, they would have arrived in the late afternoon / early evening on Day 6. This would have allowed them to hold the Euripus strait while resting overnight, and then join the coordinated attack the following morning against the Greek positions on land and sea. For one possible route of the fleet, see Bowen (1998), $362-363$. 
mainland Greece would slow their pace, the Persians probably expected their forces to land behind Greek lines sometime in the evening of Day 6 or the morning of Day $7 .{ }^{12}$

Xerxes may have suspected that his ships had been destroyed in the storm that struck on the night they had set out, but he had no way of knowing for certain. ${ }^{13}$ In any case, it would not make sense for his ground forces to launch an all-out assault on the Greek position before the flanking movement could conceivably be carried out. Thus the fighting on Day 5 and Day 6 was probably more intended to probe Greek defenses and maintain close contact than to overwhelm them via sustained frontal attacks on their position at the Gates. ${ }^{14}$ In the event that Leonidas attempted to withdraw in order to escape the trap being set by the circumnavigation, the King's forces would be closely positioned to seize the Phocian Wall and to inflict casualties on the retreating Greeks. ${ }^{15}$

The small Greek army could not hope to defeat the Persian ground forces in a single, decisive engagement, and so would have to rely on a defensive war of attrition for victory on land. The only way for the Greeks to gain an immediate and decisive victory over the Persians at this point would have been to destroy the enemy ships that remained at Aphetae,$^{16}$ and so it is not surprising that the Persians also adopted a cautious approach on sea. They did not entirely avoid engaging the Greeks, but, as Herodotus reports, Greek ships were the aggressors in the fighting that did take place. They appear to have

12 As Georges (1986), 49-50 observes, Xerxes likely based his plans for the circumnavigation of Euboea on intelligence from his Greek advisors and from Persians (e.g., Artaphernes) who had participated in the 490 campaign to Eretria and Marathon.

13 The arrival of 53 triremes to reinforce the Greeks at Artemisium on Day 6 may have signaled to Xerxes that the Greeks were not afraid of being trapped in the straits and therefore that the circumnavigation had failed. Herodotus does not make this connection, but it is possible that the Greeks had positioned these ships toward the southern end of Euboea, and recalled them to Artemisum on Day 6 after receiving reports of the destruction of the Persian detachment off the island's eastern coast the night before (8.14). Bury (1895-1896), 88-89 suggests that these 53 ships were posted at the Euripus strait until the failure of the Persian circumnavigation. See also Munro (1902), 308-311; Myres (1953), 257-258; Evans (1969), 399; Georges (1986), 49-50; Rahe (2015), 234. Cf. Macan (1908), 377; Lazenby (1964), 273-274. Hammond (1988), 555 simply observes that news of the destruction of the Persian circumnavigators arrived at the same time as the Greek reinforcements.

14 How and Wells (1912), 376, "The Persian leaders, whose attacks on the first two days may perhaps have been feints intended to distract attention from their real designs, evidently aimed at turning the position, first by sending their fleet round Euboea, and then by the path Anopaea." See also Macan (1908), 378. It is for this very reason - to cover the retreat of the allies - that many have suggested Leonidas remained in the pass even after learning that the Phocians had failed. See, for example, Dascalakis (1962), 75-78; Burn (1962), 417-418; Evans (1969), 395; Simpson (1972), 6-7.

16 Matthew (2009), 17 notes that Greek ground forces were not able to inflict a decisive defeat on the Persians, but that the fleet could, even if doing so was not necessarily the Greek plan. See similar comments by How and Wells (1912), 375-376; Last (1943), 65; Ferrill (1966), 109. Against the idea that the Greek planned to strike decisively with their fleet, see Evans (1969). My main point here is not necessarily that the Greeks themselves sought a decisive engagement on the sea, but that, if they did hope to defeat Persian forces in a single engagement (rather than wage a prolonged defensive war of attrition), then their only hope was on the sea rather than on land. In turn, from a Persian perspective it made sense to avoid risking a full engagement with the Greek fleet before the day of the decisive battle on land. Balcer (1989) argues that an inability to adequately supply Persian forces led Xerxes and his generals to launch several attacks too soon and was a main factor in the invasion's failure. 
attempted to lure the Persian ships into more open waters for battle on Day 5 (8.9-12), and again attacked the King's Cilician contingent on Day 6 (8.14.2).

On Day 7, Persian ground forces did not approach the Greek position at the Gates as closely as they had on the days before, drawing out the Greek defenders further from the Phocian Wall. Meanwhile, the Persian ships at Aphetae launched a sustained assault against the Greeks stationed at Artemisium. Herodotus suggests that their motivation was shame at setbacks in the naval skirmishing over the previous days (8.15.1), but it is likely that a more intensive attack on Day 7 had been the plan all along. The King had ordered his Immortals to advance on the Anopaea on the night of Day 6, so that they would arrive in the next morning behind enemy lines. Had the detachment sailing around Euboea not been destroyed in the storm, Persian ships and marines would also have advanced against the rear of the Greeks on the same day.

The timing of the final Persian attack was not at all dictated by Xerxes' desperation or the unanticipated treachery of Ephialtes. The King used the early arrival of his army to scout out the local terrain, and upon the arrival of his fleet immediately implemented a three-pronged attack plan that would culminate on Day 7. First, the circumnavigation could have trapped the entire enemy force and, with the destruction of both the small Greek ground force and the entire Greek fleet, essentially ended the war. The second prong was the attack against the Greek fleet at Artemisium, where a decisive victory would have forced the defenders to withdraw from their position, causing a Greek retreat on land as well. The third prong, of course, was the successful march on the Anopaea, which led to the defeat of the Greeks at the Thermopylae pass and to the flight of their fleet from the straits of Euboea that evening. ${ }^{17}$

\section{The Defense of the Anopaea Path}

The question remains as to how the Persians were able to turn Leonidas' position by taking the Anopaea path, which was narrow, rocky, and guarded by 1,00o Greeks from Phocis. The failure of the Phocians was the decisive moment at Thermopylae, but it has received surprisingly little attention in accounts of the battle from antiquity to the present. Plutarch (On the Malice of Herodotus 32) and Diodorus of Sicily (11.8.4-8, 9.3) ignore the episode entirely, and most modern historians either omit it or follow the basic narrative offered by Herodotus (7.218): the sudden appearance of the Persians surprised them and, believing that they themselves were the objects of the attack, the Phocians retreated to higher ground after a single volley of arrows. Ignoring them, the Persians continued their descent behind the rear of the Greek defenders below. ${ }^{18}$

17 Despite offering a slightly different chronology of the battle, Rahe (2015), 235 also suggests that the King timed the movement along the Anopaea and the full naval assault at Artemisium to coincide with the potential arrival of the ships that had attempted the circumnavigation.

18 Grundy (1901), 299-300; Macan (1908 vol. 2), 282-283; Grant (1961), 17; Burn (1962), 415-418; Dascalakis (1962), 54; Hignett (1963), 145-147; Evans (1964), 234; Lazenby (1964), 271 and (1993), 141-142; Wallace (1980), 23; Olmstead (1948), 252; Hammond (1988), 557, (1996), 14-19; Dandamaev (1989), 200-201; Bal- 
Yet there are obvious problems with Herodotus' apologetic account of the Persian advance on the Anopaea. ${ }^{19}$ He writes that the Phocians had set no pickets or guards at all along the path or before their camp, and were asleep until they heard the noise of the Persian approach. Contrary to the assertions of some modern historians, there is evidence from ancient sources that setting guards around military camps was standard practice already by the time of the Persian invasion. ${ }^{20}$ Notably, Herodotus offers no criticism of this grave error, which ultimately led to the slaughter of their Greek allies and to the loss of the pass below.

After recovering from their initial surprise, Herodotus notes that the Phocians were able to arm themselves as the Persians approached. Even so, they abandoned their position after one barrage of arrows. Again, Herodotus does not offer any negative comment on their retreat, portraying their actions as confused but nonetheless heroic. Once on higher ground, he states that they prepared to die manfully, thinking themselves the object of the attack. But the defense of the path was critical to the entire Greek war strategy, and the Persians were obviously marching along it to bypass Leonidas' position, not to kill the Phocians themselves. That they made no effort to block or even delay the Persian advance due to a misunderstanding of the purpose of their task is, quite simply, not believable. ${ }^{21}$

Even granting that the Phocians may have been surprised and withdrew in a momentary panic, their failure to regroup and launch a counter-attack remains problematic. The Persians would have been vulnerable to a charge against their flank from higher ground as they passed the Phocian position. They also would have been vulnerable to an attack from behind - again, from higher ground - after they had passed the Phocian position and were on their descent to the Gates. In this way, the Phocians could have turned the tables on the Persians, surrounding them even as they attempted to do the same to Leonidas and his allies at the Thermopylae pass itself. ${ }^{22}$

cer (1995), 252; Green (1996), 138-139; Szemler, Cherf, and Kraft (1996), 71-75; Cartledge (2007), 146-147; Matthew (2009), 21-23; Rahe (2015), 234-235; Stoneman (2015), 135.

19 Several of these arguments were first made by Munro (1902), 314-315, but have since fallen out of favor. See further discussion below.

20 Lazenby (1993), 141-143 argues that pickets or scouts would not be usual for the time, but in his subsequent discussion of the Phocian defeat contradicts this claim by suggesting that the Spartans became aware because they themselves had posted "daywatchers" on the path, In fact, Herodotus 8.27 mentions Thessalians setting pickets in their earlier invasion of Phocis, and Krentz (2007), 165-166 notes several references to pickets and sentries already in the Iliad. Szemler, Cherf, and Kraft (1996), 74-75 speculate that the Persians and their Thessalian allies advanced under cover of darkness to neutralize the Phocian pickets, but do not explain why Herodotus denied their existence.

21 How and Wells (1912), 376 suggest that the Phocians may not have anticipated an attack because Trachis was held in front of them. However, if access to their position required an advance defensive perimeter breach, it is odd that Herodotus does not mention so and difficult to understand why the Greeks, so heavily outnumbered, would have stationed them on the path, essentially as reserves, in the first place.

22 In a similar vein, Bury (1895-1896), 101-104 and Grundy (1901), 305-310 suggested that Leonidas had dispatched his allies not to retreat entirely when learning that the Phocians had failed, but to attack Hydarnes and the Persians from both sides as they descended the Anopaea and entered the pass. Against this, Lazenby (1993), 144; Hammond (1996), 17 n. 44. 
Perhaps the Persians recognized the threat the Phocians would have continued to pose from their position and left some number of soldiers behind to protect their own rear, but Herodotus is silent on the matter. ${ }^{23}$ If they were trapped on the mountainside, did they surrender? And if they were not, why, again, did they not try to help Leonidas before it was too late? Even as Herodotus details how the rest of the Greeks escaped, surrendered, or were killed by the Persians, we receive no comment on what became of the Phocians. The very fact that he has sources enough to narrate their experience in even a limited manner suggests that some, if not all, survived. ${ }^{24}$ Indeed, their absence from the casualty lists and memorial traditions of the final stand at Thermopylae indicates that they did not fight to the death, and probably did not resist at all. ${ }^{25}$

Herodotus' apology on behalf of the Phocians is not convincing. The reality is that they were given a critical assignment, and had at the least several days to select and prepare to defend their position..$^{26}$ As Last observed, "it is scarcely credible that they can have been assigned a task which, if events called for its performance, their numbers were completely inadequate to discharge". ${ }^{27}$ Yet it is quite clear that they did not even delay the Persians. Herodotus makes no mention of the Phocians resisting after the first discharge of arrows against them, and his chronology of the march leaves little time for further action. ${ }^{28}$

Comparative evidence casts their failure in starker relief. In the Battle of Thermopylae of $279 \mathrm{BCE}$, the Greeks once again assigned the defense of the Anopaea to their Phocian contingent, this time 3,000-strong. ${ }^{29}$ Facing the Romans roughly eighty years later, Antiochus III tasked allied Aetolians to defend the Anopaea path with 1,0oo soldiers - the same number as the Phocians before them. ${ }^{30}$ As in 480 , the defenders of

An important feature of Herodotus' defense of the Phocians is his selective presentation and omission of information. For more on Herodotus' use of omission, see Lateiner (1989), 59-75.

24 Macan (1908), 322, "perhaps the words, unnecessarily strong, have come from a source favorable to the Phocians."

25 On the memorials composed for the dead at Thermopylae and the traditions surrounding the battle in antiquity, see discussion by How and Wells (1912), 230-231; Bowra (1933); Podlecki (1968); Molyneux (1992), 175-187; Flower (1998), 369-372; Cartledge (2007), 153-174; Trundle (2013) and (2018); Brown (2013).

26 The hill near Nevropolis was the most likely location for the Phocian position, according to Pritchett (1958), 209-210 and (1982), 196 n. 50. Mackay (1963), 254-255 and Wallace (1980), 18 n. 22 agree, and provide maps identifying the location.

27 Last (1943), 64.

28 There are several different theories as to the exact route taken by the Persians. See, for example, Grundy (1901), 300-303; Munro (1902), 313-314; Pritchett (1958); Hignett (1963), 361-370; Wallace (1980); Pritchett (1982), 176-210; Szemler, Cherf, and Kraft (1996), 105-112; Rapp (2013), 53. Pritchett (1982), 198201 questions the utility of modern attempts to test the timing of the hike along the Anopaea, and therefore to ascertain its exact course, but nonetheless argues for the accuracy of Herodotus' chronology.

29 Pausanias 10.20.3 records 3,000 Phocians were present, but does not describe their deployment in detail. At 22.9-11, he notes the presence of two possible routes around Callidromus, but states only that the Gauls took the same route as Hydarnes and the Persians, and that it was defended by an unspecified number of Phocians. It is therefore plausible that the Phocians defended each possible route with half of their soldiers, much as the Aetolians did in 191.

30 According to Livy 36.16 and Appian Syrian Wars 4.18, 2,000 Aetolians held Hereclea, while 1,00o each took up a position along the two paths, one being the Anopaea, around Mt. Callidromus. 
the path in 279 and 191 were attacked at times of low visibility either at night or under heavy fog, but were still able to hold their position and offer battle for some time. While in both instances they were ultimately defeated, their experience is evidence that 1,00o Phocians should have been sufficient to offer some resistance to the Persians and at least delay their advance. ${ }^{31}$

Rather than suggest that they were given an impossible task, most scholars have explained the Phocian failure as a result of simple cowardice or incompetence. ${ }^{32}$ However, every other anecdote Herodotus mentions reveals the Phocians implementing the very tactics - seizing the high ground, forcing battle in narrow terrain, and setting ambushes - we would expect from a people with experience resisting larger armies in the mountains. During a previous war against the Thessalians, for instance, they surprised an invading army as it climbed the slopes of Mt. Parnassus at night, covering their bodies and armor with white chalk both to distinguish themselves from and terrify their foes (8.27). In another encounter, they crushed the Thessalians by luring their cavalry into a narrow pass where they had buried empty pots. When the enemy horse charged, their hooves fell into the pots, which tripped them and broke their legs (8.26).33

Herodotus does not indicate that the Phocians lost their resourcefulness or courage in the decades following their war against Thessaly. To the contrary, the Phocians who remained loyal to the Greek cause after Thermopylae harassed Persian supply lines from their refuge on Mt. Parnassus (9.31.5). Those who collaborated with the Persians are reported to have demonstrated bravery and discipline in the face of a threatening Persian cavalry maneuver upon their arrival at Plataea (9.17-18). As some of the most experienced and capable Greeks at fighting in the mountains, they should have had been aware of the need to set a watch through the night and understood that their defeat was not the ultimate aim of the Persian attack force. Perhaps these otherwise stalwart warriors merely suffered a momentary lapse one night on the Anopaea path, but it is worth considering an alternative explanation: that they betrayed their Greek allies at the Gates below.

Scholars questioned the loyalty of the Phocian contingent at Thermopylae already in the late nineteenth and early twentieth centuries. The strongest advocate of this view was Munro, who cast doubts on what he called Herodotus' "lame apology" for the Phocians in a 1902 article. Munro suggested that the Phocian defensive position was at a fork on the Anopaea path, where one route entered Phocis itself and the other circled back behind the Greeks at Thermopylae. Faced with the difficult choice of defending their

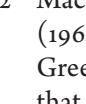
this Plutarch Mulierum Virtutes 2 and Pausanias 10.1.3-11 also give similar accounts. See further discussion of these events below. 
homeland or their allies upon the sudden arrival of the Immortals, they selfishly but understandably made the decision to abandon Leonidas and guard the road into Phocis. ${ }^{34}$

Munro's hypothesis is tactically and topographically problematic, however, and suggestions that they betrayed their allies have unsurprisingly fallen out of favor. ${ }^{35} \mathrm{It}$ is difficult to believe that the Phocians would have selected a position that forced them to choose between guarding a passage into their homeland and defending their allies. ${ }^{36}$ Moreover, while the probable Phocian position near Nevropolis may have been in front of a possible footpath into Phocis, it was not a major road in antiquity and was not a route taken by the Persian army following the victory at Thermopylae. ${ }^{37}$

Nonetheless, there remain good reasons to suspect that they betrayed their allies. Most significant is Herodotus' silence on their fate after the battle. Given his eagerness to narrate heroic acts of resistance in general, this silence is a strong sign that their actual actions were quite shameful in the eyes of later Greeks. Either the Phocians somehow escaped home, abandoning the high ground to which they had fled and on which Herodotus claims they were prepared to fight to the death, or they surrendered without a fight and joined the Persian cause. The latter possibility seems most likely to me, and it would explain why Herodotus reports that the Phocian contingent that fought for the Persians at Plataea in 479 was exactly the same size as the force stationed on the Anopaea the year before..$^{38}$

\section{The Phocian Resistance in the Cephisus Valley}

It is a challenge to identify the Phocians traitors at the Anopaea and to explain their motivation, in large part because Herodotus presents the Phocians in the best light pos-

34 Munro (1902), 314-319. See also Myres (1953), 251; Gomme (1956), 397-398; Cawkwell (2005), 119 n. 22. How and Wells (1912), 227 add that "clearly all this is an answer to current charges of medism and cowardice." Grant (1961), 17-18 and Evans (1964), 233-234 offer some criticism of these views as they pertain to Leonidas' decision to remain in the pass.

35 Munro (1964), 297 n. 1 himself later softened his suggestion, noting that while "Herodotus is clearly primed with apologies for them, their treachery is not proven." The most recent reference to their betrayal that I have been able to locate is Hignett in (1963), 147, but here the possibility is only briefly mentioned and simple incompetence is instead advocated. See also How and Wells (1912), 227; Last (1943), 64.

36 Hignett (1963), 135-136 persuasively criticizes Munro's placement of the Phocians, and Pritchett (1989), 119-120 demonstrates claims that the Phocians were forced to choose between defending their homeland and Leonidas' rear are topographically impossible.

37 The likely route of Xerxes' army into Phocis was first identified as a Mycenaean road by Kase (1973). Kase and Szemler (1982) further elaborated on the exact course of this road and its use by Xerxes' army. Pritchett (1982), 211-233 and Londey (2013), 138-143 agree, and point out that it was also used by other armies in antiquity. Many, e.g., How and Wells (1912), 243-244; Rahe (2015), 247-248, suggest that at least some part of the Persian force continued on via Thermopylae. McInerney (1999), 55-56 offers a clear summary of these roads. For the Phocian position on the Anopaea at Nevropolis, see n. 26.

38 Macan (1908), 624, similarly comments that the 1,000 Phocians at Thermopylae and later at Plataea were "no doubt very much the same men. The anecdote here has the 'tendency,' the intention, to whitewash the Phocian Chiliad, whose reputation had been somewhat blasted by the Spartan (Peloponnesian) story of Thermopylae." 
sible throughout the Histories. ${ }^{39}$ For instance, he writes that the Thessalians attempted to extort them in exchange for protection from the Persians after Thermopylae. In the process of explaining why they rejected this extortion, he relates several anecdotes about the resourceful Phocian resistance against Thessaly a few decades earlier (discussed above). He then highlights the extent of the suffering these resistors experienced in 480 . I have already mentioned that they were forced to abandon their homes and seek refuge on Mt. Parnassus. In his account of the Persian progression through Phocis after Thermopylae, Herodotus identifies by name fifteen Phocian settlements and sanctuaries they destroyed $(8.33-35) .^{4^{\circ}}$ To put this figure in context, Herodotus does not name any individual places destroyed in Attica apart from the acropolis, and in Boeotia only mentions the razing of Thespiae and Plataea $(8.50,9.13)$.

Despite his emphasis on their resistance and suffering, Herodotus acknowledges that there were Phocians who did in fact join the Persians at the Battle of Plataea. Even here, however, he offers the excuse that they did so only because they had been compelled (9.17.1). He then includes a brief story about how this Phocian contingent was nearly attacked by the Persian cavalry upon its arrival, the implication perhaps being that the Persians did not trust their loyalty (9.17-18). He further lessens the impact of Phocian collaboration by stating that they did not participate in the sacking of Athens (9.17.1), and were among the Greeks who did not try very hard during the battle itself (9.67). Finally, his account of the retreat of Artabazus after Plataea includes the comment that the Persian general was fearful of revealing the battle's result to the Phocians, but not to the Thessalians (9.89).

For all of the apologetic details and anecdotes that Herodotus supplies regarding the people of Phocis in the Histories, he is curiously silent on a number of important points. He does not explain why some Phocians collaborated and others resisted, he does not say when or how this split occurred, and he does not specify which Phocians fought the Persians and which ones joined them. Just the opposite, his account most often speaks of the Phocians as a unified people: "the Phocians" resist the Thessalians prior to the Persian Wars, "the Phocians" send soldiers to aid the Greeks at Thermopylae, and "the Phocians" reject Thessalian blackmail after the battle (7.176, 203, 215, 8.27-32).

Yet the very specificity of Herodotus' apology for Phocis in other respects provides enough clues for us to reconstruct the nature of Phocian resistance for ourselves. The Persian destruction path was heaviest in the Cephisus Valley. It extended westward along the Sacred Way at least as far as Daulis, not coincidentally near where the Phocian federal meeting building, or Phokikon, was located. The Phocian state had been

One reason for the apologetic treatment of Phocis must be that Herodotus relied on Phocian sources, as observed by Nyland (1992), 94-96. Macan (1908), 10-11 also notes his use of Delphic traditions and oracles. Despite what I view as quite obvious Phocian favoritism, it should be noted that others, e. g., Evans (1991), 92, have followed Plutarch (On the Malice of Herodotus 35) in viewing Herodotus' statements toward them in a more negative light. On Herodotus' depictions of the decision to medize by various Greeks states (though not Phocis), see Baragwanath (2008), 203-239.

40 Herodotus lists them in the following order: Drymaia, Charadra, Erochos, Tithronion, Amphikleia, Neon, Pedieis, Triteia, Elateia, Hyampolis, Parapotamioi, Abai, Panopeos, Daulis, and Aiolidai. 
born out of the revolt against Thessaly ca. 510. One major engagement of this conflict was fought at Hyampolis, at the southern end of the Valley; another was near Tithora, a peak overlooking Neon on the eastern slope of Parnassus (8.27-28). This was, in fact, the exact same place where the Phocian resistance was based during the invasion of Xerxes. ${ }^{41}$ After defeating the Greek coalition at Thermopylae, then, the Persians specifically targeted the Phocian federal state - both its primary population centers along the Cephisus and its federal building near Daulis - for destruction. ${ }^{42}$

According to Herodotus, the Persians ravaged Phocis at the behest of the Thessalians. In relaying this information, Herodotus gives the impression that the Phocians joined the anti-Persian alliance out of self-preservation rather than a broader commitment to an independent Greece or a sense of camaraderie with their allies (8.30). This, in turn, could be viewed as the reason why they retreated from the Anopaea rather than risk their lives to protect the Greek forces at the Gates. In light of the widespread destruction of their homeland after the fall of the pass, however, any such decision to abandon their allies below would have been extremely shortsighted and disastrously counterproductive. ${ }^{43}$

Making matters worse, their enemies in Thessaly appear to have viewed the Persian invasion as an opportunity to do more than merely to punish the Phocians. Following Thermopylae, the Thessalians asserted that it was within their power to dispossess the Phocians of their territory and even to enslave them, and so demanded heavy payments - i.e., tribute - in return for protection from the Persians (8.29). Whether the Phocian federation joined Leonidas and the rest of the Greeks for selfish reasons or out of some higher-minded idealism, they had the most to lose at Thermopylae out of any of the allies, and should have been as committed to the success of the mission and the broader anti-Persian campaign as any other group present. Persian success at the Gates meant the temporary loss of their homes, and Persian success in the war itself would have meant the restoration of Thessalian hegemony over Phocis, which had ended only three decades earlier.

The Phocians of the Cephisus Valley, then, had no reason to betray Leonidas. Thermopylae guarded the less direct of the two major roads from northern Greece into Phocis. There was another road along its border with Doris, one actually taken by a significant portion of the Persian army after the battle. It would have been strategically necessary to protect this route in addition to Thermopylae, and the Phocians who lived along the Cephisus and whose settlements depended most directly on its security were best suited to the task. The position lost its strategic importance once Thermopylae fell

41 For this revolt and the establishment of the Phocion federal state and the Phokikon, see McInerney (1999), 175-181 and further references in n. 6 above. On the Phokikon specifically, see French and Vanderpool (1963); French (1984); Fossey (1986), 95-96.

42 On the absence of the Phokikon from Herodotus' list of destroyed Phocian settlements, see McInerney (1999), 179-180.

43 As mentioned above, these Phocians continued to harass Persian supply lines from Parnassus rather than sit out the remainder of the conflict (9.30), hardly behavior one would expect from a group committed only to self-preservation. 
and the second path into Phocis via Hyampolis at the southern end of the Valley was open. No longer able to block the Persian advance into their homeland, these Phocians withdrew to the stronghold on Mt. Parnassus and sent their families further west. ${ }^{44}$

The reason ancient sources do not mention any Greek presence on the road between Doris and Phocis is that there was no fighting there. ${ }^{45}$ Notably, however, Herodotus does not preclude a Phocian presence there either. In his survey of the muster at Thermopylae, he notes that the Locrians sent their entire hoplite levy, while the Phocians sent 1,000 soldiers. This wording leaves open the possibility that Phocis could raise more than the soldiers sent to Thermopylae, and this is confirmed by the fact that later in the war some Phocians resisted the Persians from Parnassus while 1,000 others fought alongside them at Plataea. It is not unreasonable to infer that the remainder of the Phocian military force was stationed at the only other route into the Cephisus Valley, whence they had been levied. ${ }^{46}$

\section{Delphi, Phocis, and the Persians}

It is most plausible that the Phocians who collaborated with the Persians were based west and south of Parnassus at Delphi. This region does not appear to have suffered at all at the hands of the Persians and, in contrast to Abae and numerous other Greek sanctuaries, Delphi was not sacked or plundered. The reason for this is not because the Persians simply did not pass through the area. Herodotus reports that a division of troops was sent to Delphi, but defeated through miraculous, divine intervention: first, a rock-fall killed many Persian soldiers, and then the survivors were chased away by two local, larger-than-life heroes dressed as hoplites. Tellingly, he does not suggest that the

44 In an unnecessary contradiction to Herodotus due to their strident belief that a road into central Greece could not have passed through Thermopylae itself, Kase and Szemler (1982), 364 place the 1,00o Phocians at Pergara above the Dhema Gap rather than at Nevropolis on the Anopaea. Pritchett (1985), 190-216, (1989), 118-122, and (1991), 194-205 quite persuasively criticized their entire reconstruction of events, which stray far from the ancient source material. See also Cawkwell (2005), 274-276. The occupation of this route by the remainder of the Phocians, suggested recently by Cawkwell (2005), 276 and Rahe (2015), 213, 224, would answer the question raised by Londey (2013), 149, echoing Hignett (1963), 134: "why Xerxes did not simply ignore the defenders [at Thermopylae] and go the other way" into Phocis via Doris. I would further suggest instead that these Phocians - that is, those not dispatched to join Leonidas, but the ones who defended the Dhema Gap road - were stationed at the village of Oiti or at Kastro Orias, a strategically fortified site discussed by Mackay (1963), 67; Pritchett (1982), 216-226; and Kraft et al. (1987), 195; Green (1996), 115. For a map with these locations identified, see Kase and Szemler (1982), 354. Rapp (2013) offers a recent survey of the scholarship on the local topography at Thermopylae in 480 .

45 Macan (1908 vol. 2), 269-272 suggests another plausible and not mutually-exclusive factor: that any operations that took place on this route were omitted by Herodotus due to the historian's reliance on Spartan sources, who were mainly concerned with the legacy of Leonidas.

46 Beloch (1931), 99 already suggested that the Phocians could have mustered additional forces. Cawkwell (2005), 276, adds, "it is highly likely that in 480 the Phocians could field a good many more than the thousand Herodotus talks about. Where were they then? It seems all too probable they were ready to help defend Doris and that the Dorians 'were taking the side of the Mede' (8.31) only after the Greek failure at Thermopylae." 
Phocian resistance based on Parnassus played any role in stopping the Persian approach. Rock falls in this region are common, and Herodotus' comment that he himself, decades later, saw some rocks on the roadside - the very ones, he claims, that fell upon the Persians - is hardly convincing evidence to support the story. ${ }^{47}$

In reality, the Persian mission was probably welcomed at Delphi rather than killed en route. The stories of miraculous protection are nothing more than an attempt to explain why the sanctuary had not been sacked along with the other settlements of Phocis after Persia's defeat, when the oracle's collaboration had become an embarrassment. Herodotus cites priests from the sanctuary as his sources, and scholars have long recognized that they provided him with material designed to sanitize the sanctuary's behavior before and during the war. ${ }^{4}$ Although he does record oracles to Athens and Sparta suggesting that victory was possible, in the estimation of many, these were post-war revisions to the sanctuary's initial responses that had encouraged many Greek states to surrender or at least remain neutral. ${ }^{49}$ The priests even allowed Gelon of Syracuse to send money to Delphi to give to Xerxes in the event that the Persians were successful (7.163)..$^{\circ}$

In the face of this evidence, several scholars have attempted to prove that the sanctuary at Delphi did not medize. One argument is that most of the oracles relating to the Persian invasion were revised or entirely fabricated in the decades that followed, and so cannot be taken as evidence of the sanctuary's stance during the invasion. ${ }^{51}$ Even granting this hypothesis, however, the contents of many of these revisionist oracles advocate against resistance to the Persians, meaning that later Greeks accepted the possibility that the priests had medized and premised their own self-serving oracles upon it.

A second argument holds that the oracles delivered to Athens and Sparta were not only authentic, but also unequivocally anti-Persian. Yet the proposed chronology in this reconstruction, which situates all of these oracles in the nine days immediately follow-

47 Hammond (1988), 565 n. 84 writes "complete skeptics have to account for the arrival of the great rocks," but what evidence could there possibly be to confirm that these rocks fell in 480 and not at some other time before Herodotus visited? How and Wells (1912), 246, note, "Herodotus' account of the deliverance of Delphi is obviously a temple legend told the author by Delphic priests." See also the skeptical comments by Fairbanks (1906), 42; Macan (1908), 408-415 and (vol. 2), 234; Burn (1962), 425-426; Lazenby (1993), 151-152; Balcer (1995), 258; Rösler (2013), 243; Rahe (2015), 248-250. Kindt (2016), 47-48 observes that Herodotus reports the episode as a storyteller, carefully keeping his own analytic voice separate, and therefore avoids staking his own credibility on its accuracy.

48 For the relationship between Delphi and the Persians, see Munro (1902), 320; Fairbanks (1906); Macan (1908 vol. 2), 229-237; How and Wells (1912), 245-247; Casson (1914) and (1921); Roussel (1927); Burn (1962), 345-349; Hignett (1963), 439-447; Balcer (1989), 137; Lefèvre (1995), 25; Green (1996), 165. According to the list compiled by Shrimpton (1997), 259-265, Herodotus names Delphian sources on three occasions: 1.20, 1.51.3, 8.38-39.1. Hornblower (2002), 378 surveys previous literature on Herodotus' reliance on sources from Delphi, and notes that "the Delphians' are explicitly named as a source very early in the history... but their evidence is far more pervasive than the explicit citations would suggest." See also Kaplan (2006), 138-139; Rösler (2013), 241-246; Kindt (2016), 47.

49 Most notably Fontenrose (1978), 77-78, 124-128; Graf (1979), 181-186. On the malleability of not only the interpretation, but also the delivered contents of the oracles, see Evans (1982); Georges (1986), 31-37; Maurizio (1993), 113-128. Crahay (1956), 295-337 offers a detailed argument against the veracity of nearly all of the oracles relating to the Persian invasion (addressed below).

50 Fairbanks (1906), 42; How and Wells (1912), 199; Brunt (1953), 158-162.

51 Crahay (1956), 295-342. 
ing the defeats at Artemisium and Thermopylae, is of questionable plausibility. ${ }^{52}$ Moreover, the interpretation of the oracles as unequivocally supporting resistance is belied by Herodotus' report that some Athenians - the divination specialists, no less - believed that the Pythia's advice to trust in the wooden walls meant that they should permanently abandon their city and migrate west (7.143.3).53

Debate over the interpretation and authenticity of the oracles aside, the main issue remains that Delphi, "such a rich jewel, deep in Persian territory for much of the war, survived without a scratch" ${ }^{54}$ One possible explanation is that the Thessalians and other Greeks who had joined Xerxes simply intervened to prevent any harm from coming to the sanctuary, ${ }^{55}$ but others have long recognized that this is in fact an argument in favor of Delphi's medism..$^{56}$ Doris was also spared at the behest of the Thessalians, and Herodotus clearly counts them among those who joined the King (8.31). Indeed, it is likely that the Thessalians intended to use Persian support to reestablish their control over the oracle, and that the priests themselves welcomed this possibility (see discussion below).

A related suggestion is that Delphi, purportedly like many of the northern Greeks states, adopted an official policy of neutrality in the war. ${ }^{57}$ But most of north and central Greece did submit upon the approach of the Persian army, so this argument, too, supports the position that Delphi medized..$^{8}$ Moreover, there is no evidence that the King allowed any other state confronted by his armies in Greece to remain neutral the choice, after all, was to submit earth and water or, in refusing, to declare war (e.g., $6.48-49,94 ; 7.138) .59$ The neutrality of states such as Argos and Achaea was widely recognized as de facto medism even in antiquity, and was reportedly encouraged by the oracle (7.148). ${ }^{60}$ While these states were prevented from aiding the King due to their proxim-

52 Georges (1986), 28-29 places the delivery of the oracles to Athens and Sparta immediately after Thermopylae and Artemisium. In this span of nine days from the Persian victory at the Gates to the arrival of the Persian fleet at Phalerum, the Athenian representatives - whom he speculates must have already been at Delphi - are claimed to have learned of the defeats and returned with an oracular response to Athens, where the Athenian assembly decided to confront the Persians at Salamis and carried out the evacuation of the city.

53 Georges (1986), 26 n. 28 dismisses the oracle's initial reported response to abandon hope against Persia without any clear rationale (7.140-141). His argument is also self-refuting, since he later (p. 37) claims that it was easy for states to misrepresent the contents of oracular responses "with no one the wiser." By this logic, whatever reports the Athenian delegates delivered to the assembly should not be taken as Delphi's response or policy, but as the opinion of the delegates themselves.

$54 \mathrm{Scott}(2014), 114$.

55 Georges (1986), 28 n. 30. Crahay (1956), 341 makes the same argument.

56 As Macan (1908), 398 observes, "If Delphi escaped their [the rest of the Phocians'] fate, its escape may have been due to the very different attitude of the Thessalians (and other medizing states) to Phocis and to the Amphictyonic shrine." See also Burn (1962), 425-426; Lazenby (1993), 151-152.

57 Scott (2014), 116, expanding on comments made by Crahay (1956), 342.

58 For medism in north and central Greece, see Gillis (1979), 60; Graf (1979), 155-181.

59 Similarly, Cyrus II refused to allow the Ionian Greeks to remain neutral during his war against Croesus, and following his victory punished those who had earlier refused to submit to him $(1.76,141)$.

6o See Nielsen (2007) and Waters (2014) for Argos; Freitag (1996) for Achaea. Delphi also advised the Cretans against intervening on behalf of the anti-Persian alliance (7.169). 
ity to Sparta in the Peloponnese, can it really be doubted that the Argives in particular would have joined the Persians had they broken through the isthmus at Corinth ${ }^{61}$

Those who reject the medism of Delphi also deny that the Persians ever attempted to visit the sanctuary. It has been argued that the trip was not worth the trouble, since the oracle "lay at the terminus of a difficult route," and, if any of Xerxes' soldiers did make the journey, they would have been "merely undisciplined looters" ${ }^{62}$ Plainly, this is not a convincing reason to reject Herodotus' report of the expedition. Delphi was the wealthiest, most influential sanctuary in the Greek world, and it defies reason that the King would have ignored it merely because the road was too difficult. ${ }^{63}$

An alternative proposal is that that Herodotus' priestly sources invented the Persian expedition to Delphi in order to "give the city and sanctuary at least some honor and crucial role" in the war. ${ }^{64}$ But surely it is more reasonable to think that the story recorded by Herodotus is the result of an attempt by the priests to offer an apologetic interpretation of what in hindsight was an embarrassing visit by the Persians, rather than to believe that they invented the visit itself whole cloth. Indeed, if the priests had taken the liberty to completely fabricate a self-serving account of their actions during the war, they were remarkably inept. Rather than demonstrate proof of the oracle's honor, their quite obviously incredible anecdote has instead convinced many of its medism ${ }^{165}$

Another suggestion is that the Persians avoided Delphi because their general Mardonius had received an oracle stating that the invasion would fail if any harm came to it (9.42).$^{66}$ Once again, however, this interpretation actually relies on evidence that favors collaboration: in effect, it suggests that the Persians did consult the Pythia, and received a response indicating that the conquest of Greece would be successful so long as Delphi itself was spared. Moreover, this argument does not acknowledge that Herodotus immediately dismisses the veracity of this particular oracle - thus eliminating it as a reason for dismissing the existence of the expedition to the sanctuary - by claiming that it was delivered to Illyrians rather than the Persians (9.43). The priests of Delphi in Herodotus' time would have of course been keen to discredit any report that their forebears had given the shrine's blessing to the Persian invasion, and so it is telling that they

61 Much as Argos' non-participation at the Battle of Chaereonea in 338 was a sign of its support for Philip II. After his victory, Philip rewarded the Argives with territory taken from Sparta, and in turn the Argives helped install a pro-Macedonian faction in power at Elis. See Rop (2017), 311; Tomlinson (1972), 144-146; Roebuck (1948), 76. As Munro (1902), 302-303 noted long ago, the possibility that Argos would openly medize and attack was likely a major factor in Sparta's unwillingness to empty the Peloponnese of soldiers and send a large army north to Thermopylae.

62 Georges (1986), 28 n. 30.

63 Kaplan (2006), 130-139 notes that the Persians, like their Phrygian, Lydian, and Egyptian predecessors, were well aware of the oracle's significance.

64 Crahay (1956), 335; Scott (2014), 116-118.

65 As Graf (1979), 187-188 observes, "it seems almost certain that the legendary tale was created to conceal some embarrassment suffered by the priests at Delphi."

66 Scott (2014), 116. This explanation is also promoted by Kindt (2016), 49. On the plausibility of Mardonius consulting the oracle, see Graf (1979), 188-190. Crahay (1956), 97 notes that the priests must have had a stock oracular response that warned invaders against sacking the sanctuary (see also p. 291-293 for his discussion of this particular tradition). 
challenged only the prophecy's audience, not its existence. The mere fact that Herodotus undertakes the effort to repudiate this oracle is a sign that reports of the sanctuary's collaboration with Persia continued to circulate in the late fifth century.

Finally, it has been claimed that Delphi's potential medism is not consistent with the numerous, expensive dedications made at the sanctuary by the victorious Greeks after the wars. ${ }^{67}$ Yet few medizers were actually punished by the anti-Persian alliance, ${ }^{68}$ and the ambiguities in many of the surviving oracular responses indicate that Delphi hedged its support for the invaders sufficiently to avoid being completely discredited. More importantly, the withdrawal of Persian forces from Greece likely meant that the Phocians of the Cephisus Valley regained control of the sanctuary. ${ }^{69}$ Because the oracle was no longer in the hands of Persian collaborators, there is no need to see any contradiction in the post-war dedications to Apollo and the wartime behavior of the Delphians. ${ }^{70}$

To those familiar with the political history of the sanctuary, the split between the Delphians and the Phocians of the Cephisus Valley should come as no surprise. Whereas north and east Phocis had chafed under Thessalian rule in the sixth century, Delphi prospered. Thessaly's intervention in the First Sacred War ca. 590 had expanded the sanctuary's territory at the expense of nearby rival Crissa, which was annihilated. It had also established the sanctuary's autonomy from the rest of Phocis: rather than being dominated by its neighbors, Delphi enjoyed self-governance under the protection and guidance of the Amphictyonic Council, which was controlled by Thessaly.1

Ancient sources make no explicit comment on the status of Delphi vis-à-vis the rest of Phocis in the wake of the expulsion of the Thessalians, but it is reasonable to think that the Phocians took control of the sanctuary as part of their broader program of political unification, which included minting coins in the name of all Phocis and establishing the Phokikon near Daulis. Located on the Sacred Way between the sanctuary and the southern terminus of the Cephisus Valley, Daulis was also the easternmost site razed by the Persians in the region. Delphi's escape from destruction was not mere coincidence or the happy consequence of a miraculously timed and aimed rock fall, but a sign that much as they had done in the First and would do in the Second and Third Sacred Wars -

67 Bowden (2005), 27-28; Scott (2014), 117.

68 Gillis (1979), 80-81.

69 McInerny (1999), 188 notes that the next mention of Phocis in ancient literary sources occurs in relation to events in the year 458 , when the Phocians are presented as a unified polity in control of Delphi (Plutarch Kimon 17.3).

70 A similar argument is made by Graf (1979), 190-192. Nielsen (2007) suggests that the medism of Argos may also be one reason (among others) for the lack of dedications by the Hellenic League at Nemea after the wars, but crucially there was no change in control over this sanctuary as there probably was at Delphi. For background on this conflict and Delphi's historical relationship to Thessaly and the rest of Phocis, see Macan (1908), 408; Forrest (1956) and (1957); Lehmann (1980) and (1983); Brodersen (1991), 3-9; Davies (1994); Lefèvre (1995), 24-25; McInerney (1997) and (1999), 162-174; Howe (2003). Robertson (1978) denies the historicity of the First Sacred War; while his analysis has not been widely accepted, he does not reject the two elements about the episode most important for my argument here: 1) Thessalian control over Phocis for much of the sixth century, and 2) that there was a long-running animosity between Delphi and the rest of Phocis. On pro-Persian sentiments in Thessaly, see Graf (1979), 159-168. 
the priests and inhabitants of Delphi offered themselves as clients to an external power in exchange for autonomy from the rest of Phocis..$^{2}$

As part of the Phocian federal state in 480 , the Delphians had little choice but to join the rest of Phocis in responding to the summons of Leonidas and the Spartans. They must have provided all or a substantial portion of the 1,000 Phocians who went to Thermopylae, where they volunteered to guard the Anopaea path. They were stationed there for several days after the arrival of the Persian army and its Thessalian allies - again, formerly the protectors of Delphi - thereby leaving the time and the interlocutors to negotiate the terms of their betrayal. Notably, the Thessalians also helped protect the Thebans and the Dorians from suffering harm at the hands of the Persians after Thermopylae $(7.233 ; 8.31)$.

One may reasonably question why the Phocians would have chosen to dispatch potentially unreliable soldiers from the furthest reaches of their territory to Thermopylae. In fact, I would suggest that this is exactly the best place for such troops. Sending the troops from Delphi to Leonidas allowed them to contribute to the coalition army gathering there, while still allowing those from the Cephisus Valley to defend the most direct route to their homeland. Even if the rest of the Phocians were already suspicious of the loyalty of the troops from Delphi, it would have been reasonable to believe that their ability to harm the allies and the rest of Phocis would be diluted in a larger force of Greeks and by Thermopylae's distance from the oracle. They could not have known that the Delphians would volunteer to guard the Anopaea alone, or that Leonidas would allow them to do so without supervision.

It is impossible to know whether the betrayal by the Phocians from Delphi was negotiated at some point during the six days prior to the Persian march on Anopaea, or simply occurred in the form of an immediate surrender during the night attack itself. In either case, the end result was the same: the Phocian federal state and its heartland in the Cephisus Valley was demolished by the Persians, while Delphi was spared destruction, re-gained its autonomy, and sent the same 1,00o men who had served at Thermopylae to join the Persian invasion of Boeotia and Attica. This scenario also explains the otherwise puzzling Persian response to the arrival of the Phocians at the start of the campaign season the following year: since some Phocians were actively resisting, Mardonius ordered his cavalry to surround these Phocians to ensure that they were indeed his allies, whom he would and did recognize on sight from their surrender on the Anopaea, before allowing them to enter the Persian camp near Plataea.

It is true that this argument relies on a good deal of informed speculation. Yet it is also true that Herodotus' account is full of apology for the Phocians, and that he was in a position to provide clarifying details that could have made his case on their behalf

72 Phocian desire for control over Delphi, and Delphian desire for independence from Phocis, was a common cause of conflict in Phocis throughout the fifth and fourth centuries, including but not limited to the Second and Third Sacred Wars. See Larsen (1968), 42-45; Roux (1979), 17-19; Buckler (1989), especially 11-29, 196-204; Beck (1997), 109-118; McInerney (1999), 186-226; Buckler and Beck (2008), 213-223. For Delphi's resistance to Macedonian hegemony and its evolving relationship with the rest of Phocis after the Third Sacred War, see Arnush (2000), 299-307. 
even stronger. If they really did not betray the Greeks on the Anopaea, why does he not tell us what became of the 1,000 stationed there? If they were not the same 1,000 who later fought for the Persians at Plataea, why not make it clear, perhaps by revealing the name of the Phocian commander at Thermopylae? Why does he not state which of the Phocians collaborated, which resisted, and when the split between the two sides took place? In each case, the best explanation is that Herodotus, unquestionably a sophisticated narrator and not a modern historian interested in supplying a full and objective account, simply omitted these details because they undermined his apologetic agenda. ${ }^{73}$ The story he wrote is therefore as positive as it could be for the Phocians in general and for priests of Delphi in particular, both at Thermopylae and throughout much of the war.

The realization of their betrayal by the Phocians does not lessen the heroic sacrifice of those who perished at Thermopylae, but it does shed new light on the competence of the Persians in the battle itself. Their victory was not due to mere chance or the unsolicited treachery of a single individual, but was instead secured thanks to good military intelligence, a sound tactical plan, and a keen understanding of local Greek politics. Despite suffering a weather-induced catastrophe, Xerxes and his army drove their heavily armored Greek foes from a highly defensible position in a mere three days, opening the way into central Greece and even into Attica. In addition to killing an enemy leader, nearly three hundred of his elite soldiers, and over a thousand other Greek resistors, the King also secured additional Greek troops for his own army as well as the support of the most prominent sanctuary in all of Greece.

\section{Bibliography}

Arnush, M. 2000. "Argead and Aetolian Relations with the Delphi Polis in the Late Fourth Century BC." In Alternatives to Athens. Varieties of Political Organization and Community in Ancient Greece, edited by R. Brock and S. Hodkinson, 293-307. Oxford: Oxford University Press.

Balcer, J. M. 1989. “The Persian Wars against Greece: A Reassessment.” Historia: Zeitschrift Für Alte Geschichte 38: 127-143.

- 1995. The Persian Conquest of the Greeks 545-45o BC. Konstanz: Universitätsverlag Konstanz. Baragwanath, E. 2008. Motivation and Narrative in Herodotus. Oxford: Oxford University Press.

Beck, H. 1997. Polis und Koinon. Untersuchungen zur Geschichte und Struktur der griechischen Bundesstaaten im 4. Jahrhundert v. Chr. Stuttgart: Franz Steiner Verlag.

Beloch, K. 1931. Griechische Geschichte. Vol. 2 Part 2. Berlin: Walter De Gruyter.

Bowden, H. 2005. Classical Athens and the Delphic Oracle: Divination and Democracy. Cambridge University Press.

Bowen, A. 1998. "The Place That Beached a Thousand Ships." The Classical Quarterly 48: 345-364. Bowra, C. M. 1933. "Simonides on the Fallen of Thermopylae." Classical Philology 28: 277-281. Briant, P. 2002. From Cyrus to Alexander: A History of the Persian Empire. Winona Lake: Eisenbrauns. Brodersen, K. 1991. "Heiliger Krieg und Heiliger Friede in der frühen griechischen Geschichte." Gymnasium 98: 1-14.

73 Wiseman (1993), 146 suggests that lying by omission was a common device used by ancient historians, one that has been underappreciated by modern scholars. For Herodotus' use of it, see n. 23 above. 
Brown, A. 2013. "Remembering Thermopylae and the Persian Wars in Antiquity." In Beyond the Gates of Fire: New Perspectives on the Battle of Thermopylae, edited by C. Matthew and M. Trundle, 100-116. Barnsley: Pen \& Sword.

Brunt, P.A. 1953. “The Hellenic League against Persia." Historia: Zeitschrift für Alte Geschichte 2: $135-163$.

Buckler, J. 1989. Philip II and the Sacred War. Leiden: Brill.

Buckler, J., and H. Beck. 2008. Central Greece and the Politics of Power in the Fourth Century BC. Cambridge: Cambridge University Press.

Burn, A. R. 1962. Persia and the Greeks: The Defence of the West, c. 546-478 B. C. London: Edward Arnold.

Bury, J. B. 1895-1896. "The Campaign of Artemisium and Thermopylae." The Annual of the British School at Athens 2: 83-104.

Cartledge, P. 2007. Thermopylae. The Battle That Changed the World. New York: Vintage Books.

Casson, L. 1991. The Ancient Mariners: Seafarers and Sea Fighters of the Mediterranean in Ancient Times. Princeton: Princeton University Press.

Casson, S. 1914. "The Persian Expedition to Delphi." The Classical Review 28: 145-151.

- 1921. "АПО $\triangle \mathrm{EI} \Xi \mathrm{I} \Sigma$, 'Inventory,' in Herodotus and Thucydides." The Classical Review 35: 144145 .

Cawkwell, G. 2005. The Greek Wars: The Failure of Persia. Oxford: Oxford University Press.

Crahay, R. 1956. La littérature oraculaire chez Hérodote. Paris: Les Belles Lettres.

Dandamaev, M.A. 1989. A Political History of the Achaemenid Empire. New York: E. J. Brill.

Dascalakis, A. 1962. Problèmes historiques autour de la bataille des Thermopyles. Paris: Boccard.

Davies, J. 1994. "The Tradition of the First Sacred War." In Greek Historiography, edited by S. Hornblower, 193-212. Oxford: Clarendon Press.

Evans, J.A. 1964. “The 'Final Problem' at Thermopylae." Greek, Roman, and Byzantine Studies 5: 231-237.

- 1969. "Notes on Thermopylae and Artemisium." Historia: Zeitschrift für Alte Geschichte 18: 389406.

- 1982. "The Oracle of the "Wooden Wall." The Classical Journal 78: 24-29.

- 1991. Herodotus, Explorer of the Past. Three Essays. Princeton: Princeton University Press.

Fairbanks, A. 1906. "Herodotus and the Oracle at Delphi." The Classical Journal 1: 37-48.

Ferrill, A. 1966. "Herodotus and the Strategy and Tactics of the Invasion of Xerxes." The American Historical Review 72: 102-115.

Flower, M.A. 1998. "Simonides, Ephorus, and Herodotus on the Battle of Thermopylae." The Classical Quarterly 48: 365-379.

Fontenrose, J. 1978. The Delphic Oracle. Its Responses and Operations with a Catalogue of Responses. Berkeley: University of California Press.

Forrest, W. G. 1956. "The First Sacred War." Bulletin de Correspondance Hellénique 80: 33-52.

- 1957. "Colonisation and the Rise of Delphi." Historia: Zeitschrift für Alte Geschichte 6: 160-175.

Fossey, J. M. 1986. The Ancient Topography of Eastern Phokis. Amsterdam: J. C. Gieben.

Freitag, K. 1996. "Eine vergessene Notiz zur Geschichte Achaias im 5. Jahrhundert v. Chr. bei Hero$\operatorname{dot}(8,36,2)$." Historia: Zeitschrift für Alte Geschichte 45: 123-126.

French, E. 1984. "New Finds at the Phokikon." In Studies Presented to Sterling Dow on His Eightieth Birthday, edited by A. L. Boegehold. Durham: Duke University Press.

French, E., and E. Vanderpool. 1963. "The Phokikon." Hesperia 32: 213-225.

Georges, P. B. 1986. "Saving Herodotus' Phenomena: The Oracles and the Events of 480 B. C." Classical Antiquity 5: 14-59.

Gillis, D. 1979. Collaboration with the Persians. Wiesbaden: Franz Steiner Verlag.

Gomme, A. W. 1956. A Historical Commentary on Thucydides. Volume 2: Books 2-3. Oxford: Clarendon Press. 
Graf, D. 1979. "Medism: Greek Collaboration with Achaemenid Persia.” University of Michigan.

Grant, J. R. 1961. “Leonidas' Last Stand.” Phoenix 15: 14-27.

Green, P. 1996. The Greco-Persian Wars. Berkeley: University of California Press.

Grundy, G. B. 1901. The Great Persian War and Its Preliminaries. London: William Clowes and Sons.

Hammond, N.G.L. 1982. "The Narrative of Herodotus VII and the Decree of Themistocles at Troezen." The Journal of Hellenic Studies 102: 75-93.

- 1988. "The Expedition of Xerxes." In The Cambridge Ancient History Volume 4: Persia, Greece and the Western Mediterranean, c.525 to 479 BC (Second Edition), edited by J Boardman, N. G. L. Hammond, D. M. Lewis, and M. Ostwald, 518-591. Cambridge: Cambridge University Press.

- 1996. "Sparta at Thermopylae." Historia: Zeitschrift für Alte Geschichte 45: 1-20.

Hignett, C. 1963. Xerxes' Invasion of Greece. Oxford: Clarendon Press.

Hornblower, S. 2002. "Herodotus and His Sources of Information." In Brill's Companion to Herodotus, edited by E. Bakker, I. de Jong, and H. van Wees, 373-86. Leiden: Brill.

How, W. W., and and J. Wells. 1912. A Commentary on Herodotus. Vol. II. Reprint, 1975. Oxford: Clarendon Press.

Howe, T. 2003. "Pastoralism, the Delphic Amphiktyony and the First Sacred War: The Creation of Apollo's Sacred Pastures." Historia: Zeitschrift Für Alte Geschichte 52: 129-146.

Immerwahr, H. R. 1966. Form and Thought in Herodotus. Cleveland: Press of Western Reserve University.

Kaplan, P. 2006. "Dedications to Greek Sanctuaries by Foreign Kings in the Eighth through Sixth Centuries BCE.” Historia: Zeitschrift Für Alte Geschichte 55: 129-152.

Kase, E. 1973. "Mycenaean Roads in Phocis." American Journal of Archaeology 77: 74-77.

Kase, E., and G. Szemler. 1982. “'Xerxes” March through Phokis (Her. 8, 31-35).'” Klio 64: 353-366.

Kindt, J. 2016. Revisiting Delphi: Religion and Storytelling in Ancient Greece. New York: Cambridge University Press.

Kraft, J., G. Rapp, G. Szemler, C. Tziavos, and E. Kase. 1987. “The Pass at Thermopylae, Greece.” Journal of Field Archaeology 14: 181-198.

Krentz, P. 2007. "War." In The Cambridge History of Greek and Roman Warfare, edited by P. Sabin, H. van Wees, and M. Whitby, 147-185. Cambridge: Cambridge University Press.

Larsen, J. A. 1968. Greek Federal States. Their Institutions and History. Oxford: Clarendon Press.

Last, H. 1943. “Thermopylae.” The Classical Review 57: 63-66.

Lateiner, D. 1989. The Historical Method of Herodotus. Toronto: University of Toronto Press.

Lazenby, J.F. 1964. "The Strategy of the Greeks in the Opening Campaign of the Persian War." Hermes 92: 264-284.

- 1993. The Defence of Greece, 490-479 B. C. Warminster, England: Aris \& Phillips.

Lee, J.W. 2007. A Greek Army on the March: Soldiers and Survival in Xenophon's "Anabasis." Cambridge: Cambridge University Press.

Lefèvre, F. 1995. "L'Amphictionie de Delphes: mythe et réalité." Cahiers du Centre Gustave Glotz 6: 19-31.

Lehmann, G.A. 1980. "Der 'Erste Heilige Krieg' - eine Fiktion?” Historia: Zeitschrift für Alte Geschichte 29: 242-246.

- 1983. “Thessaliens Hegemonie über Mittelgriechenland im 6. Jhdt. v. Chr." Boreas 6: 35-43.

Londey, P. 2013. "Other Battles of Thermopylae." In Beyond the Gates of Fire: New Perspectives on the Battle of Thermopylae, edited by C. Matthew and M. Trundle, 138-149. Barnsley: Pen \& Sword.

Macan, R. W. 1908. Herodotus: The Seventh, Eighth, and Ninth Books. Volumes 1 \& 2. Reprint, 1973. New York: Arno Press.

Mackay, P. A. 1963. "Procopius' De Aedificiis and the Topography of Thermopylae." American Journal of Archaeology 67: 241-255.

Matthew, C. 2009. "The Strategy of the Thermopylae-Artemisium Line in 480 BC." Ancient History: Resources for Teachers 39: 1-24. 
- 2013. "Was the Greek Defence of Thermopylae in 480 BC a Suicide Mission?" In Beyond the Gates of Fire: New Perspectives on the Battle of Thermopylae, edited by C. Matthew and M. Trundle, 60-99. Barnsley: Pen \& Sword.

Maurice, F. 1930. “The Size of the Army of Xerxes in the Invasion of Greece 480 BC.” The Journal of Hellenic Studies 50: 210-235.

Maurizio, L. 1993. "Delphic Narratives: Recontextualizing the Pythia and Her Prophecies.” Princeton University.

McInerney, J. 1997. "Parnassus, Delphi, and the Thyiades." Greek, Roman, and Byzantine Studies 38: 263-283.

- 1999. The Folds of Parnassus. Land and Ethnicity in Ancient Phokis. Austin: University of Texas Press.

Molyneux, J.H. 1992. Simonides: A Historical Study. Wauconda, IL: Bolchazy-Carducci.

Munro, J.A. 1902. "Some Observations on the Persian Wars (Continued)." The Journal of Hellenic Studies 22: 294-332.

- 1964. "Xerxes' Invasion of Greece." In Cambridge Ancient History. Vol. IV. The Persian Empire and the West, edited by J. D. Bury, S. A. Cook, and F.E. Adcock, 268-316. Cambridge: Cambridge University Press.

Myres, J. L. 1953. Herodotus, the Father of History. Oxford: Clarendon Press.

Nielsen, T.H. 2007. "A Note on the 'Hellenic League against Persia' and the Sanctuary of Zeus at Nemea." Classica et Mediaevalia 58: 165-178.

Nyland, R. 1992. "Herodotos' Sources for the Plataia Campaign." L'antiquité Classique 61: 80-97.

Olmstead, A. T. 1948. History of the Persian Empire. Chicago: University of Chicago Press.

Podlecki, A.J. 1968. "Simonides: 480." Historia: Zeitschrift für Alte Geschichte 17: 257-275.

Pritchett, W. K. 1958. "New Light on Thermopylai." American Journal of Archaeology 62: 203-213.

- 1982. Studies in Ancient Greek Topography. Part IV (Passes). Berkeley: University of California Press.

- 1985. Studies in Ancient Greek Topography. Part V. Berkeley: University of California Press.

- 1989. Studies in Greek Topography. Part VI. Berkeley: University of California Press.

- 1991. Studies in Ancient Greek Topography. Part VII. Amsterdam: J. C. Gieben.

Rahe, P.A. 2015. The Grand Strategy of Classical Sparta. The Persian Challenge. New Haven: Yale University Press.

Rapp, G. 2013. “The Topography of the Pass at Thermopylae Circa 480 BC.” In Beyond the Gates of Fire: New Perspectives on the Battle of Thermopylae, edited by C. Matthew and M. Trundle, 39-59. Barnsley: Pen \& Sword.

Robertson, N. 1978. "The Myth of the First Sacred War." The Classical Quarterly 28: 38-73.

Roebuck, C. 1948. "The Settlements of Philip II with the Greek States in 338 B. C." Classical Philology 43: 73-92.

Rop, J. 2017. "The Historical Context of the Reply to the Satraps Inscription (IG IV 556)." Journal of Ancient History 5: 304-322.

Rösler, W. 2013. "Ein Wunder Im Kampf Um Delphi (VIII 35-9) - Schlagendstes Beispiel von Quellenfiktion Durch Herodot? Kritische Retraktationen Zum Herodotbild von Detlev Fehling." In Herodots Quellen - Die Quellen Herodots. Classica et Orientalia, Bd 6, edited by B. Dunsch and K. Ruffing, 241-253. Wiesbaden: Harrassowitz Verlag.

Roussel, P. 1927. "Hérodote et l'expédition des Perses contre Delphes." Revue des Études Anciennes 29: 337-340.

Roux, G. 1979. L.'Amphictionie, Delphes et le temple d'Apollon au IVe siècle. Lyon: Boccard.

Sacks, K. 1976. "Herodotus and the Dating of the Battle of Thermopylae." The Classical Quarterly 26: $232-248$.

Scott, M. 2014. Delphi: A History of the Center of the Ancient World by Michael Scott. Princeton: Princeton University Press. 
Shrimpton, G. 1997. History and Memory in Ancient Greece. Montreal \& Kingston: McGill-Queen's University Press.

Simpson, R. H. 1972. "Leonidas' Decision." Phoenix 26: 1-11.

Stoneman, R. 2015. Xerxes. A Persian Life. New Have: Yale University Press.

Szemler, G., W. Cherf, and J. Kraft. 1996. Thermopylai: Myth and Reality in 480 BC. Chicago: Ares Publishers.

Tomlinson, R. A. 1972. Argos and the Argolid: From the End of the Bronze Age to the Roman Occupation. Cornell University Press.

Trundle, M. 2013. "Thermopylae." In Beyond the Gates of Fire: New Perspectives on the Battle of Thermopylae, edited by C. Matthew and M. Trundle, 27-38. Barnsley: Pen \& Sword.

- 2018. "Spartan Responses to Defeat: From a Mythical Hysiae to a Very Real Sellasia." In Brills Companion to Military Defeat in Ancient Mediterranean Society, edited by J. H. Clark and B. Turner, 144-161. Leiden: Brill.

Van Wees, H. 2004. Greek Warfare: Myths and Realities. London: Duckworth.

Wallace, P. 1980. "The Anopaia Path at Thermopylai." American Journal of Archaeology 84: 15-23.

Waterfield, R. 2006. Xenophon's Retreat: Greece, Persia and the End of the Golden Age. London: Faber and Faber.

Waters, M. 2014. "Earth, Water, and Friendship with the King: Argos and Persia in the Mid-Fifth Century." In Extraction \& Control: Studies in Honor of Matthew W. Stolper, edited by Matthew W. Stolper, Michael Kozuh, Wouter Henkelman, Charles E. Jones, and Christopher Woods, 331-336. Studies in Ancient Oriental Civilization, Number 68. Chicago, Illinois: The Oriental Institute of the University of Chicago.

Westlake, H. D. 1936. "The Medism of Thessaly." The Journal of Hellenic Studies 56: 12-24.

Wiseman, T. P. 1993. "Lying Historians: Seven Types of Mendacity." In Lies and Fiction in the Ancient World, edited by C. Gill and T. P. Wiseman, 122-146. Liverpool: Liverpool University Press.

JEFFREY ROP

University of Minnesota Duluth, 265 AB Anderson Hall, Duluth, MN 55812, USA

jarop@d.umn.edu 